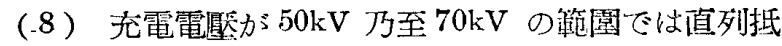
抗のない場合の放射 X線のアルミニウム牛價磨は芚 電電厴に大體比例して大となる。

日本熙祭放射線學會雜誌，12，1，(昭27)

$$
\mathbf{X} \text { 線多色撮影法 }
$$

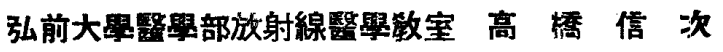
大日本塗料株式會社茅ゲ崎工場 大 谷 信 吉

X線多色撮影法には技術的に2つの方法がありその 第一はテクニカラー法に相當するもので種々な露出條 件にて數枚のX線寫俱を撮つた後で種々の色で夫々染 色し々れ教重称て觀察する方法である。第二は多層乳 劑方式による天然色撮影である。種々なる露出條件に て1枚の天然色>ィルムに數司のX線露出，與へる。 此の際艋感紙は各露出每に取換えられて染色劑の役目 封する。ここには後者すなわち多層乳劑方式夫然色つ イルムにX線撮影子る方法, 實驗結果實用結果に就 述べてある。

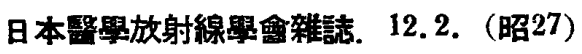

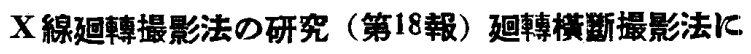
於ける曼及び線影像の生成に就的ての寒駿的研究

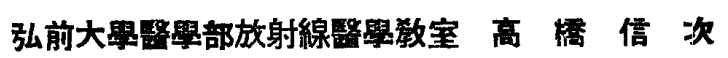

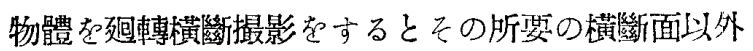
の部分は最かされる。此の暈はX線像の鮮鉸度を害す る文晕像は互に重複して所謂核影像及び線影像をつく

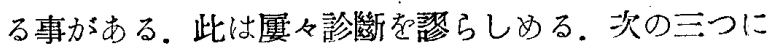
就いて夫々理諭的考察起行つて此の最の生成に與加る 法則夿知りそれにより作圖を行つた後で模型につき横 斷撮影起行つてその理論的考察の誤りでない事を實䙞 する方式坴執つてある。
（1）點加所要の橫綝面以外に存在する場合.

（2）線若しくは面か所要の横斷面以外で然も此と平 行な面に含まれている場合。

(3) 線若しくは面方所要の棤断面と交わる平面に含 まれている場合。

そして研究結果として（1）照は圓として最汁その 位置並びに牛徑都決定してあり。（2）線は2本の線 で緣どられた曲帶となつて聂ける。（3）面は曲帶と なり暈ける。となつて居る。

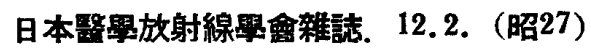

\section{$\mathbf{X}$ 線間接撮影裝置を構成する要秦の單獨分解

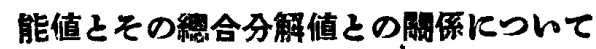 \\ 岛洋製作所レントゲン工場 藤 本 慶 治 \\ 佐野博也}

間接撮影裝置を構成する要素の單獨分解能と备要素 を總合した總合分解能との關係について實驗式と理論 式と教求め現在の間接撮影の改良すべき點学探究しそ れ老改良向上することに上りとの程度總合分解能值か よくなるかか計算出來る方策を示してある。

\section{ホトタイマーの試作（第 1 報）}

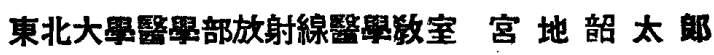 手 蒠}

間接撮影用 Phototimer の試作であり，二次電子頊 倍管と C.R 包路並びに Relay 包路教使用し基楚的實 驗灾完了して一應まとまつた裝置の製作に成功。之在 用いたモデル實驗並びに人體撮影實驗では實用電壓， 電流, 胸厚の範園內で略々滿足すべき均一黑化度が得 られて居る。

THE AMERICAN JOURNAL OF ROENTGENOLOGY AND RADIUM THERAPY

$\begin{array}{lll}\text { VOL. } 66 & \text { JULY }(7 月) & \text { NUMBER } 1\end{array}$

本號は數多くの腫瘍とか脈管系統とか胃腸の診斷・ に必要な技眞的部門の發表が見當らなかつた。 治源方面の臨休的・實驗的研究の報告がなさ，音々

\title{
THE AMERICAN JOURNAL OF ROENTGENOLOGY AND RADIUM THERAPY
}

VOL. 66 AUGUST (8月) NUMBER 2

本號には，放射性沃度（1131)による甲狀腺疾患の治 療に關する研究が二編，新生兒の胃腸に關市る研究が 三編之の他臨休的な研究報告が多數揭載されている。 吾々に必要な技術的部門として，立體寫傎觀察法に關
する報告と焱末に揭載されている「文臷拔萃」より耐 容量に關する二・三の抄錄を茲に照介する。

立體鏡式レントゲン蔫要要莪

By LEWIS E. ETTER, M.D. 